\title{
Occasions for Decay
}

\author{
Aritha van Herk
}

Kelva, le personnage de l'histoire d'Aritha van Herk, erre sans cesse, mais son errance est moins une errance physique qu'une agitation permanente provoquée par une jaunisse qui afflige son corps. Quelle est cette maladie, demande la narratrice, qui isole et met en quarantaine une femme qui ne souhaite pas socialiser? Prudemment, Kelva scrute le contour des portes, provoquant des enjambements textuels qui dépassent de beaucoup son entendement. Son objectif est un corps qui s'investit dans des psychologies qui la poussent à la guérison en même temps qu'elle résiste et aspire à la maladie. Peut-être que guérison est le mot qu'il faut à un tel personnage. Antidote serait-il plus approprié ? Ou remède? Ou encore cicatrisation?

The cause of Kelva's jaundice is a late snowfall drifting green through wilting streetlights, bolstering every branch and bush, twiggy scribbles gone blurred and nubular.

Kelva turns yellow-almost-green. The creases of her arms at the hinge of her elbow darken, there her mortis point, acrostic, and although she twists to see the invisible backs of her knees, another no molesten, she has to imagine her skin's pale darkening. She'll have to pay a lover to kiss it better.

Kelva's breath stirs the hair of countless imaginary lovers, their stumbling sleep, their fallen arches, the way they duck around doorways to avoid being photographed. They lie sprawled wide across her bed long past the closing of sententious noons.

Pale feces and dark urine. Kelva pokes glasses over her ears and reads descriptions of jaundice. The books describe other people, other jaundices, serious and hemolytic, subjects of obstruction, stagnation. Incurable as coincidence. Not hers. Cholestasis. Bilirubin.

Kelva shudders with the knell of these symptoms, their declarative strength welling up from her body's urn and swarming the edges of her skin. But she's a mild case, anemic, her blood nothing more than uncooperative, sluggish.

These soundings leak across the pages of medical texts, of lay composi- 
tions, of neonatal advice. They do not mention a fault-finding gaze or the French ancestry of the jaundiced eye. Or even the stale dregs of Latin bile, swinging between choler and melancholy.

Kelva's not melancholy, only ungrateful.

Kelva reads Tolstoy - again. Why can't she learn to stay away from him, his wheatfield pronouncements, his nervous comportment with largesse? His bloated arrangements make her turn green-yellow with rage, but she gulps down pages that fire and brimstone right down to her belly. And her doctor has warned her to give up stimulants.

"Clearly all disasters, or an enormous proportion of them, are due to the dissoluteness of women."

Kelva tries to remember who made this audacious claim, then decides it can be recuperated. She pictures women with their hair astray, full of weeds, their pubic hair dreadlocked and neatly trussed with pink ribbons, their public head-hair gathering debris.

She pictures women drinking from misshapen bottles, clear green liquid, the letters on the label wavery and blurred, as if splotched by weather.

Drinking reminds Kelva that she is in love with elbows, their tip and lift, their akimbo bossy for vaporub and grease. Elbows slide off the page, slip from the edges of books, fall off the table. Knights of the elbow toss dice across worn pages, fictional gamblers quote the long odds. Close-mouthed stories wait close at hand. And as for room, the elbow is a hustler, a hook, a busy-body, an intrusive narrator.

The body's busy. Snatch and resurrect. A lazy liver.

The cause of Kelva's jaundice is crude enough to be a cure, but not quite, more crowd than corduroy, the same corduroy that was historically silk, although now corduroy is resiliant, tough-minded cotton - capable of withstanding wear, prone to a whipping. Now vaguely ivory, Kelva's skin retains the whalemarks, reluctant to release their imprintation. She can write between the lines, a declaration, a confession, a letter to skin editors. She uses gold pen to note names and phone numbers, reminders of errands, the times that movies start.

But jaundice has an effect, and Kelva practises irritation, sublime irritation, itchy irritation. She aims for the off-colour moment that initiates slide and slice, nothing to do with missions or objectives but evasions, how to get out of town before having to pay a fine, re-pay old loans and their bristling formalities, fling back the covers on an already stale polymer, its 
loden weave, its bookend weight.

Kelva perfects the secondary urge of the secondary plot. She narrows her eyes and peers cautiously around the hand-thumbed edges of door frames, with their peeling paint worn thin by a digest of shoulders. As if a doorway could walk through itself. Or frame a tale, painted doors outlined by lintels.

Her predecessor nimble as a coyote crossing an Alberta field. A coyote determined to be coyote, smiling with surety, fuck pronunciation and finality and puritanical waste management, there has to be room for a round of howls, a traipse past margins and across invisible city limits. Roam free, lurk from copses, snack on mice.

Kelva, when she is with jaundice, is a woman who refuses to buy her brassieres at Sears, who semaphores the glass cases of bakeries with her fingerprints, jabs the buttons of phones just to raise a ring and a bewildered hello. She dyes her hair, two notches above the discretion of blonde, a shrieking yellow.

Preoccupied with lintels. A fictional device, structurally supportive. Brace or insole, brick or standing stone. Good for unsettling setting. Let the rafters groan.

Kelva an elephant of remembrance, eager for a sleeve to crease an iron, a ladder to gain a rung, an ear to twitch or burn. She tabulates these signs, assigns them to movitation and measurement, notches the sides of pages with their moral implications. But that's a cumbrous trick, the thumbnotched measures on Roget's Thesaurus. It's passé, now, only old-fashioned dictionaries wear those round bites, letters stamped on the half-coin findings.

For Kelva, a parked car on the shoulder is a turning point. She changes direction, swings a U-turn back up Crowchild until she's taking revenge on soft shoulders, the verges of roads that run toward fields and across sloughs, impatient for the definition of ditch.

Saddest of all, Kelva's monstrously normal: no black widow, no flower, no predator, none of those handy admonishments.

La femme est un maladie.

\section{Maladie.}

Defective, erring on the side of biology and its microscopes. Their own story to tell, fermmes that is, full of test-tubes and incubations, flu bugs that multiply without cause, clothes splotched with what could pass for tomato sauce, gardens sour with tanglevines. Shaved and anti-perspired, 
nipped and tucked, q-tipped and lacquered.

She is her own anatomy.

Ungrateful Kelva. Her lovers bite her just a little too hard. Her tires wear unevenly. Lies jump out of her mailbox, flamboyant with greed. Her yard attracts debris.

As a child she lost ribbons in ditches, performed autopsies on mice, rubbed ink into her earlobes. She still uses her forefinger to pry honey and peanut butter out of broad-mouthed jars. Always a cause eager to extend amnesty.

They all, those children of her lost memory, sniffed dandelions, blotting their noses yellow.

As if the jaundice isn't sufficient, Kelva dislocates her jaw. Before the jaundice. A predisposition, an accident, a next-to-the-cheekbone assignation, an earlobe enjambment.

Dislocated jaws are common, the books say. The body trapping itself. Getting punched in the face is the usual turning point, but yawning, that classic dénouement, will do it. The jaw is notorious for narrative instability, creaky cause and effect, celebrated as the most commonly dislocated joint. O. Henry took it literally, the surprise ending, agape.

Kelva refuses to be doleful. Or fractured.

She persuades a friend to correct her dislocation.

The instructions say that another person, a friend, a partner, a fixer, should stand directly in front of the victim. Kelva. If her friend puts her thumbs on Kelva's lower back teeth at each side and presses down, the lower jaw will click back into place. Is supposed to behave again.

Kelva retrieves her padded winter mittens from the bottom of the hall closet, makes her friend put them on because if her jaw snaps shut too quickly, she could bite her friend, causing injury without insult. A case of biting the hand that relocates you, a mis en abyme.

While they position themselves, her friend reminds Kelva that morbid jealousy is a significant cause of murder. Or fiction. Or both. And asks, does a preoccupation with sexual infidelity cause misalignments of the jaw?

No, the jaw, that hinged mandible, the only mobile bone of the face, Kelva groans, is its own anarchy.

Her friend raises one eyebrow.

They both crave jealous lovers, replete with spyglasses and foreshadowing, have discussed how to acquire that stock apparatus. Hire an actor, 
they conclude.

Kelva's jaw snaps back, and she does bite her friend, not viciously, but suddenly, hard enough for her to say ow. Still, the operation is a success. The body returned to its setting.

But now Kelva's jaundiced, turned yellow.

Yellow's a frightful colour to meet in the mirror, no matter what time of day, forget the morning and its suggestive remarks. Green-tinged yellow, a barbiturate tone, a yolky package without that crumbly heat of the yolks that Jerez refuses to eat, boiling the eggs and then dissecting them, cutting them into halves and spooning the egg's centre out. The yolks pop greenly from their white margins, separate and bald.

"Bad for you," Jerez tells Kelva, while she mouths their round grease, reluctant to waste.

Jerez looks for potential illnesses, eager with his predictions. "All seems infected that the infected spy."

Pope was the critic. Still is.

Kelva eats yolk, pulls her sleeves down over her hands, wears a paintlayer of make-up. Wears sunglasses. Grows accustomed to her chemical pallor, wearing her liver on her sleeve.

Jaywalking past narratee's cross-hatch, a careless cause and effect.

The doctor prescribes exercise. Kelva takes up weight training, hoping to make her lintels more muscular, her body a plot so solid and impermeable you could punch it in the stomach and it wouldn't flinch.

She starts with cans of pork and beans, lifting them from her elbows toward the ceiling. After ten days of twenty, thirty, forty arm raises each, she hoists the next larger can size, tomatos herbed and whole, tomatoes sauced and chunked, ten days of thirty, forty, fifty can raises. After the 540 $\mathrm{ml}$ size, she shifts to juice cans, tomato again, with clamato for variation, her hands cramping with the effort of holding the curved cylinders, her arms in victory push.

Her shoulders thicken. She'll have to shift to industrial size cans next, but they are less easy to discover, lurking in the back cupboards of restaurants, saving themselves for bonspiels and barometres. They've changed from cans into pails.

Kelva knows her limits. Keeps the gloves on, waits for permission to leave, to perform at penny readings where the listeners shell peanuts and stirstick drinks. Poetry is its own re-word. Fiction is a fraction.

Kelva's jaundice becomes a vague brown, then a paler apricot. She misses 
her yellow, how she could conjugate sulpher, quinoline, saffron; how it encouraged her to meditate on lemons and primroses, how she was inspired to investigate ivory and canaries, their xanthic wealth.

Kelva's jaundice fades.

She dreams that she pulls handfuls of pale straw from her body.

She re-inforces the lintel over her kitchen door, and every day does chinups, drawing herself through its liminal space toward the frame of ceiling. Her jaw stays politely located. In place. 